\title{
THE UNINVITED: REFUGEES AT THE RICH MAN'S GATE ${ }^{1}$
}

\author{
Jỗo Diogo Mateus ${ }^{2}$
}

As a result of recent international migration flows, the degree of ethnic diversity in most of the great European cities is quite remarkable, providing these cities with a distinctive and enriching multicultural flavour. The International Organization for Migration (2003) estimates the number of people who live in a country other than the one in which they were born to be around 175 million, i.e., one out of every 35 people.

This book casts some light upon the poorly known lives and worlds of those who have hidden from police searchlights in some Italian beach, who were thrown into the Mediterranean sea by smugglers trying to escape from the police, who have suffocated inside trailer trucks underneath the English Channel or who have died of thirst while crossing the Sahara. Impressive stories indeed, which author Jeremy Harding came across while interviewing immigrants and refugees in Morocco, Spain, Italy, Kosovo, FYR Macedonia and Albania in order to understand the difficulties felt by those that try, by every means available, to slip past the gates and walls of Fortress Europe. Faced with unemployment, extreme poverty and a sheer lack of any future prospects, more and more individuals feel the inevitable need to change the course of their lives and turn to emigration. In turn, others do so in order to escape totalitarian political regimes, in which summary judgements, prison torture and executions are common practices.

Within a global framework in which immigration is severely restricted, smugglers play a decisive role in the current regime of international migration. However paradoxal this might seem - considering the abuses that the migrants are put through by the smuggling networks, often linked with Mafia-type organisations, as well as the latter's sole concern with profit ${ }^{3}-$, the truth is that, for many people, this is the only way to enter the EU territory ${ }^{4}$. These illegal structures would not exist were it not for the substantial demand on the part of the economic migrants and refugees who cannot enter the EU by legal means.

Economic immigrants are the ones who pay the price of the current socio-economic situation, often being presented, in certain discourses, as people who just want to improve their livelihood, rather than actually having to escape - unlike "authentic"

1 Harding, J. (2000) - The Uninvited: Refugees at the Rich Man's Gate. Profile Books and the London Review of Books.

2 João Diogo Mateus is a Research Fellow working with the Project Reinventing Portuguese Metropolises - Migrants and Urban Governance (FCT - POCTI 38599/GEO/2001), coordinated by Prof. Maria Lucinda Fonseca. E-mail address: diogomateus@fl.ul.pt.

3 The estimated cash-flow of this illegal activity is somewhere between 5 and 7 million Euros per year. 
asylum-seekers/refugees. At the same time, the status of the refugee has been considerably weakened and eroded, leaving numerous refugees with little choice but to migrate without any legal documents. Still others have been turned down and prosecuted for being false refugees.

Numerous accounts of migrant journeys all the way from Sub-Saharan Africa, gathered by the author at the Calamocarro Refugee Center in Ceuta, show that such a hard and perilous undertaking requires some very special character traits. Thus, the author argues, these are among the most highly motivated workers anywhere to be found. The Spanish police, which patrols the walls around Ceuta, is indeed impressed by the African immigrants' courage and strength of will. However, they reduce it to the misery that they are trying to flee, rather than to the individual character of these individuals: the walls prove clearly ineffective in preventing the entry of people with such strong motivations. According to Beck and De Mas (2001), the truly relevant barriers between Northern Africa and Southern Europe are the legal ones, not the physical ones that have been constructed by the authorities.

Italy and Spain are two of the most important entry points into Europe for undocumented people and are thus subject to very close and strict surveillance. For those coming from West Africa, there are two main migration axes, both of which are controlled by smugglers: the Western axis, through which people arrive in Ceuta or Mellilla and then attempt to cross the Mediterranean; and the eastern axis, across Libya and into Turkey or Lebanon, before attempting to enter Europe alongside numerous Kurds, Kosovars, Turks, Iraqis, Albanians and even Chinese. Both the Spanish Guardia Civil and the Italian Guardia di Finanza, aboard whose boats the author witnessed several early morning pursuits and transferrals of people, know the routes and strategies of the smugglers and illegal migrants. In Italy, the gommone - the scafisti's speedboats that cross the Adriatic Sea from the coast of Albania - are chased only after the immigrants have been dropped off. As for Spain, the author maintains that it is easier for immigrants to enter the Spanish territory by ferry, under false pretenses, than to try and cross aboard the dangerous pateras. Harding states that, in 1997, 1,700 Moroccans (2,000 in 1998) were arrested in Algeciras while trying to enter Spain illegally.

The book is broadly made up of two parts: one dedicated to refugees, the other to economic immigrants. The former includes a history of the refugee flows in Europe from the 1920's to the present day, and in it the author praises the examples of solidarity that underlie that history. In this part of the book, the author also discusses the present trends in what regards asylum-granting policies and the gradual loss of importance of programmes such as the UNHCR's Refugee Relocation Programme, which by the late 1970's managed to relocate approximately one out of four refugees, as compared to a mere one out of 500 by the late 1990's. In the second part of the book, Harding discusses the importance of the emigrants' remittances for the economies of the sending countries, analyses the main reasons why people emigrate and illustrates his various points with unbelievable accounts of immigrants' attempts to reach the Europe of their dreams. The author further elaborates his analysis by providing statistical data that was either originally published by various national and international organi-sations, in the scientific literature of the field and in the media, or collected by the author himself by means of direct interviews with the people involved.

4 According to IOM estimates, the number of illegal entries per year in the EU member-states ranges somewhere between 120,000 and 500,000 (IOM, 2003). 
The gradual closing down of the legal ways for the refugees and economic immigrants to enter the hosting societies brings about the proliferation of illegal immigration and translates into a heavy burden for the immigrants and hosting societies themselves, by breeding new types of poverty and social exclusion that particularly affect the undocumented immigrants (Fonseca, 2003) and by fostering an increase in the level of interethnic conflict and a tendency towards the emergence of racist atitudes and hostile behaviours on the part of the autochtonous population.

The main criticism to which Harding's book lends itself consists in the fact that he does not suggest any specific policy recommendations that might help to address this issue. However, the need to reinforce the cooperation with the sending countries of economic immigrants, in order to overcome the present situation, as well as to devise realistic policies aimed at promoting sustainable development, are manifest throughout the book. The author argues that, for as long as the push and pull factors can be felt as intensely as they are now, the seclusion of the migrants certainly will not provide a solution to the problem - neither from the point of view of the Europeans, nor from that of the non-Europeans.

As for the main strengths of this book, one might mention the fact that it does stimulate a careful analysis of the evolution of the Europe in which we live in what regards its role as a hosting society for international migrants, and that it sheds light on what the supporters of a Fortress Europe might consider too emotional a side of the problem: the actual experiences of the prospective migrants before and during their attempts to migrate.

In order to address this issue, the harmonisation of the immigration policies at the EU level is crucial, as are community directives that are humanistic in character and pursue the interests of the Member-States, while allowing for the long-term sustainability of a social and economic model that takes into consideration the difficulties endured by other peoples and their right to pull out of misery and live a more dignified existence. At the same time, as Sassen argues, the sustainability of the present persecutory politics of migratory movements is questionable, and may, in the long run, lead to a situation much more complex than the one experienced nowadays, with higher death rates, criminalization of undocumented persons, exclusion of immigrants, strengthening of the criminal networks profiting from the current situation, and damage to the social fabric of our societies (Sassen, 2002).

FonseCA, Maria Lucinda (2003) - New directions of urban policies against social and ethnic exclusion: Lisbon experiences. In Fonseca, M. L. (ed.) - Cities in Movement: Migrants and Urban Governance. Luso-American Foundation, Lisbon (forthcoming).

IOM - International Organization for Migration (2003) - Facts and Figures on International Migration. Migration Policy Issues, 2: 1-2.

KIng, Russel; Beck, Jan Mansvelt; De Mas, Paolo (2001) - The Strait of Gibraltar: Europe's Rio Grande? In KING, Russel; BECK, Jan Mansvelt; DE MAS, Paolo (eds.) - Geography, Environment and Development in the Mediterranean. Sussex Academic Press, Brighton e Portland: p. 133.

SASSEN, Saskia (2002) - Será este o caminho? Como lidar com a imigração na era da globalização. Revista Crítica de Ciências Sociais, Dezembro 2002, 64: 41-54. 